\title{
Identifikasi Potensi Bahaya dan Risiko Keselamatan dan Kesehatan Kerja pada Pabrik Tahu House Of Tofu
}

\author{
Yofira Sintya Dewi ${ }^{1}$, Agung Ikhssani ${ }^{2}$ \\ ${ }^{1)}$ Fakultas Kedokteran Universitas Lampung, 93yofirasintya@ gmail.com \\ 2) Fakultas Kedokteran Universitas Lampung, agungikhssani@gmail.com
}

\begin{abstract}
ABSTRAK
Keselamatan dan Kesehatan Kerja (K3) secara umum didefinisikan sebagai ilmu antisipasi, pengenalan, evaluasi dan pengendalian bahaya yang timbul di atau dari tempat kerja yang dapat mengganggu kesehatan dan kesejahteraan pekerja, dengan mempertimbangkan kemungkinan dampaknya terhadap lingkungan dan masyarakat sekitar. Cakupannya cukup luas, mencakup sejumlah besar disiplin ilmu dan banyak bahaya di tempat kerja dan lingkungan. International Labour Organisation (ILO) melansir data pada tahun 2020 berisi secara global, lebih dari 2,78 juta orang meninggal akibat kecelakaan atau penyakit terkait tempat kerja, yang berarti satu kematian setiap lima belas detikLangkah-langkah dan strategi yang dirancang untuk mencegah, mengendalikan, mengurangi atau menghilangkan bahaya dan risiko pekerjaan telah dikembangkan dan diterapkan selama bertahun-tahun untuk mengimbangi perubahan teknologi dan ekonomi. Kecelakaan kerja dan industri semuanya disebabkan oleh faktorfaktor yang dapat dicegah yang dapat dihilangkan dengan menerapkan tindakan dan metode yang sudah diketahui dan tersedia. Hal ini ditunjukkan dengan terus menurunnya tingkat kecelakaan di negara-negara industri. Oleh karena itu, penerapan strategi pencegahan menawarkan manfaat manusia dan ekonomi yang signifikan. Namun, kecelakaan dan penyakit akibat kerja masih terlalu sering dan biaya mereka dalam hal penderitaan manusia dan beban ekonomi terus menjadi signifikan. Penelitian ini membahas tingkat kecelakaan kerja dan penyakit akibat kerja yang didapatkan dengan melakukan penelitian walktrough survey pada pabrik tahu "House Of Tofu" yang beralamat di Way Halim Permai Bandar Lampung. Idientifikasi keselamatan dan kesehatan kerja dilakukan dengan cara Walk Through Survey menggunakan teknik Hazard Identification, Risk Assesment, and Determining Control. Didapatkan hasil bahwa masih banyak potensi Bahaya dan Risiko Keselamatan dan Kesehatan Kerja pada Pabrik Tahu House Of Tofu yang belum teridientifikasi dan berdampak buruk bagi pekerja didalamnya. Intervensi terhadap potensi bahaya harus dilakukan oleh pengusaha untuk mengurangi angka kecelakaan kerja
\end{abstract}

Kata kunci: Keselamatan, Kerja, Pabrik, Tahu

\begin{abstract}
Occupational Health and Safety (K3) is generally defined as the science of anticipating, recognizing, evaluating and controlling hazards arising in or from the workplace that may interfere with the health and well-being of workers, taking into account the possible impact on the environment and the surrounding community. The scope is quite broad, covering a large number of disciplines and many hazards in the workplace and the environment.The International Labor Organization (ILO) released data in 2020 that globally, more than 2.78 million people die from workplacerelated accidents or diseases, which means one death every fifteen seconds Measures and strategies designed to prevent, control, reducing or eliminating occupational hazards and risks have been developed and implemented over the years to keep pace with technological and economic changes. Work and industrial accidents are all caused by preventable factors that can be eliminated by applying known and available measures and methods. This is indicated by the continued decline in accident rates in industrialized countries. Therefore, the implementation of prevention strategies offers significant human and economic benefits. However, occupational accidents and diseases are still too frequent and their cost in terms of human suffering and economic burden continues to be significant. This study discusses the level of occupational accidents and occupational diseases obtained by conducting a walk-through survey at the tofu factory "House Of Tofu" which is located at Way Halim Permai Bandar Lampung. Identification of occupational safety and health is carried out by means of a Walk Through Survey using Hazard Identification, Risk Assessment, and Determining Control techniques. The results show that there are still many potential Occupational Safety and Health Hazards and Risks at the House Of Tofu Tofu Factory that have not been identified and have a negative impact on the workers in it. Interventions against potential hazards must be carried out by employers to reduce the number of work accidents
\end{abstract}

Keywords: Safety, Work, Factory, Tofu

*Korespondensi Author : Yofira Sintya Dewi, Fakultas Kedokteran Universitas Lampung, email : 93yofirasintya@gmail.com 


\section{PENDAHULUAN}

Keselamatan dan kesehatan kerja adalah bidang yang berkaitan dengan melindungi keselamatan, kesehatan dan kesejahteraan orang yang terlibat dalam pekerjaan atau pekerjaan. Tujuan program keselamatan dan kesehatan kerja termasuk membina lingkungan kerja yang aman dan sehat Di negara berkembang, sebagian besar kecelakaan dan penyakit akibat kerja terjadi di industri primer seperti pertanian, perikanan dan pertanian, pertambangan dan konstruksi ${ }^{1}$.

International Labour Organisation (ILO) melansir data pada tahun 2020 berisi secara global, lebih dari 2,78 juta orang meninggal akibat kecelakaan atau penyakit terkait tempat kerja, yang berarti satu kematian setiap lima belas detik. Ada tambahan 374 juta cedera non-fatal terkait pekerjaan setiap tahunnya. Diperkirakan bahwa beban ekonomi dari cedera dan kematian terkait pekerjaan hampir empat persen dari Produk Domestik Bruto global setiap tahun ${ }^{2}$.

Setiap tahun lebih dari 1,1 juta orang meninggal karena kecelakaan kerja atau penyakit akibat kerja di Asia dan Pasifik. Pekerja dengan ekonomi rendah merupakan yang paling tidak terlindungi, paling sedikit informasi dan paling tidak terlatih adalah yang paling terpengaruh. Perempuan, anak-anak, pekerja difabel, pekerja migran, dan etnis minoritas juga sering dilibatkan. Tingkat pendidikan yang rendah dan pelatihan yang buruk mengenai metode keselamatan dan kesehatan kerja menyebabkan tingkat kematian yang tinggi dari masalah seperti kebakaran dan paparan zat berbahaya, dan paling berdampak terhadap pekerja pada sector industri informal $^{3}$.

Tingkat kecelakaan dan penyakit akibat kerja di negara berkembang empat kali lebih tinggi daripada di negara industri International Labour Organization (ILO) pada tahun 2018 tingkat kecelakaan kerja dan ancaman kesehatan dan keselamatan kerja di Indonesia masih berada pada level yang cukup tinggi. Banyak jenis kecelakaan industri yang masih sering terjadi dalam proses produksi terutama di sektor konstruksi, memakan korban jiwa sejumlah 6000 kecelakaan kerja setiap hari, dan di Indonesia setiap 100.000 tenaga kerja yang mengalami kecelakaan kerja sejumlah 20 pekerja terdapat kecelakaan kerja yang tergolong. Kecelakaan industri di Indonesia pada tahun 2018 menempati peringkat tertinggi di Indonesia pada 152 dari 153 negara yang disurvei ${ }^{4}$.

Sekitar seperempat dari kematian tersebut diakibatkan oleh paparan zat berbahaya yang menyebabkan penyakit yang bersifat melumpuhkan seperti kanker, gangguan kardiovaskular, gangguan pernapasan, dan sistem saraf. Kecelakaan akibat kerja terkonsentrasi di kegiatan primer dan ekstraksi seperti pertanian, penebangan, perikanan dan pertambangan beberapa industri paling berbahaya di dunia, namun industri pengelolaan makanan mencatat bahwa bahaya terpeleset, tersandung, dan jatuh adalah salah satu penyebab cedera yang paling umum di industri manufaktur makanan dan tempat kerja A.S. pada umumnya. Pada tahun 2015 saja, lebih dari 4.500 pekerja terluka karena terpeleset, tersandung, dan jatuh, dan 800 pekerja tewas dalam kecelakaan terpeleset, tersandung, dan jatuh ${ }^{5}$.

Zat berbahaya membunuh 340.000 pekerja per tahun, menyebabkan penurunan kesehatan dan penyakit yang tak terhitung termasuk kanker, penyakit jantung dan stroke. Praktik ergonomis yang buruk menyebabkan berbagai gangguan muskuloskeletal, yang mempengaruhi kualitas hidup dan produktivitas pekerja. Selanjutnya, masalah psikososial di tempat kerja seperti stres dikaitkan dengan masalah kesehatan yang serius termasuk penyakit jantung, stroke, kanker hormonal, dan berbagai masalah kesehatan mental $^{6}$.

Penelitian dilakukan pada pabrik tahu bernama House Of Tofu yang beralamat di Jl.P.Batam 6 No.7 Way Halim Permai Bandar Lampung. Industri ini dapat memproses 125-150 $\mathrm{Kg}$ kacang kedelai yang akan menjadi sekitar 12000 tahu yang akan dipasarkan ke sejumlah pasar. Dalam banyak kasus, kecelakaan kerja memiliki konsekuensi jangka panjang yang serius baik bagi pekerja maupun pengusaha. Pemiliki usaha makanan harus memiliki pemahaman yang kuat tentang hak dan tanggung jawab pada pekerja serta dilakukan pelatihan tentang cara beroperasi dengan aman di tempat kerja adalah kunci untuk meminimalkan risiko dari cedera di tempat kerja. Keselamatan dan kesehatan kerja 
pada House of Tofu diidentifikasi dengan harapan dapat meningkatkan keselamatan dan kesehatan kerja terhadap pekerja di pabrik tersebut. Penelitian ini membahas tingkat kecelakaan kerja dan penyakit akibat kerja yang menjadi potensi dengan melakukan penelitian walktrough survey pada pabrik tahu "House Of Tofu"

\section{METODOLOGI}

Penelitian ini menggunakan metode penelitian survey deskriptif dengan pendekatan observasional yang menggunakan teknik Walk Through Survey yang dilakukan kepada pekerja di pabrik House of Tofu. Walk Through Survey dilaksanakan selama 3 hari dengan melakukan pengamatan terhadap pekerja yang melakukan pemrosesan tahu yang dimulai dari penyortiran sampai tahu siap diedarkan. Tujuan dari Walk Through Survey adalah untuk mengenali dan mengidentifikasi potensi bahaya kesehatan dan keselamatan di tempat kerja. Informasi yang dikumpulkan harus menjadi dasar yang kuat untuk evaluasi kuantitatif bahaya kesehatan dan desain tindakan pengendaliannya.

\section{HASIL DAN PEMBAHASAN}

Bahaya di tempat kerja mencakup titiktitik, area, bahan, atau situasi yang dapat membahayakan, melukai, atau menyebabkan kematian dalam kasus-kasus ekstrem bagi pekerja yang berada di tempat kerja. Kondisi tersebut meliputi bahaya potensial fisik, kimia, biologi, ergonomi, maupun psikologi ${ }^{7}$.

Peneliti melakukan idientifikasi terhadap masalah pada keselamatan dan kesehatan kerja pada pekerja pada pabrik tahu House Of Tofu yang beralamat di Way Halim Permai Bandar Lampung merupakan industry berskala menengah dengan jumlah pegawai terhitung lebih dari 15 orang diluar dari distributor yang mengambil atau mengedarkan tahu dari pabrik tersebut. Setiap harinya pabrik dapat memproses 125-150 Kg kacang kedelai menjadi sekitar 12000 tahu yang akan dipasarkan ke sejumlah pasar. Idientifikasi keselamatan dan kesehatan kerja dilakukan dengan cara Walk Through Survey menggunakan teknik Hazard Identification, Risk Assesment, and Determining Control
Produksi berbagai macam tahu dilakukan di tempat yang sama. Terdapat pos atau tempat dari masing-masing proses seperti penggilingan bahan dasar tahu, perebusan, penyaringan, pencetakan, dan pengemasan tahu. Terdapat kasir sebagai tempat penjualan. Tepat di depan pabrik tahu, terlihat lapangan yang cukup luas yang digunakan sebagai tempat peletakan bahan bakar berupa cangkang sawit.

Idientifikasi kebersihan pabrik tergolong rapih dan bersih. Tempat produksi merupakan ruangan beratap tinggi namun terbuka. Lantai dari tempat produksi terlihat basah dampak dari proses pengolahan tahu yang banyak melibatkan air, namun tidak terlihat adanya genangan dimana air tidak mengalir dikarenakan adanya irigasi kecil yang membuat air bisa keluar dari tempat tersebut. Lantai juga terbuat dari semen halus yang diberi tekstur untuk mecegah pekerja tergelincir karena licin. Namun, terdapat pengecualian pada tempat kasir. Tempat kasir memiliki lantai keramik dimana lantai keramik terlihat kering. Kelembaban udara di pabrik terasa lembab dikarenakan salah satu proses di tempat tersebut adalah penguapan. Pabrik tahu ini memiliki fasilitas yang memadai disertai dengan ketersediaan air bersih yang cukup.

Dengan menggunakan standart Osha dapat disimpulkan bahwa keamanan masih kurang. Standar OSHA untuk permukaan tempat kerja, 29 CFR 1910.22, harus dapat memenuhi point berikut untuk memastikan area kerja yang bersih. Lantai ruang kerja harus bersih dan kering (bila memungkinkan), dan pengusaha harus mengurangi bahaya yang disebabkan oleh cuaca buruk, papan lepas, tumpahan, dan banyak lagi.

Pengusaha harus menyediakan drainase dan tempat berdiri kering (seperti alas lantai) ketika proses basah digunakan di pabrik pengolahan makanan komersial dan fasilitas lainnya. Semua permukaan kerja berjalan harus diperiksa dan dipelihara dalam kondisi kerja yang aman ${ }^{8}$.

Pemrosesan dimulai dari proses penyortitan kedelai, pada proses ini didientifikasi terdapat beberapa bahaya kerja berupa Fisik dan Biologi karena penggunaan alat perlindungan diri yang kurang sesuai. Pada proses perendaman biji kedelai akan memperlunak struktur sel sehingga 
akan mengurangi energi yang diperlukan selama penggilingan, selanjutnya proses penggilingan dimana biji kedelai tersebut kemudian digiling menjadi bubur kedelai. Penggilingan bertujuan untuk memperkecil ukuran partikel kedelai sehingga akan mempermudah ekstraksi protein kedalam susu kedelai. Proses pemasakan dimulai Ketika bubur kedelai yang diperoleh sebagai hasil penggilingan selanjutnya dimasukan ke dalam bak masak dengan penambahan air lagi sehingga bubur kedelai menjadi encer dan kemudian dimasak. Masalah terkena luka tusuk dan terkena luka melepuh yang dapat bersifat infeksius merupakan masalah fisik yang dapat diidntifikasi, bahaya bilogis berupa penyakit zoonosis seperti leptospirosis, terinfeksi virus, bakteri, dan mikroorganisme pada kulit tangan karena pekerja tidak menggunakan sarung tangan yang sesuai dengan standart pengolahan yang digunakan pada industri makanan.

Proses pemasakan bubur kedelai mempengaruhi kualitas tahu yang dihasilkan. Proses pemanasan secara langsung pada wajan tersebut menyebabkan timbulnya kerak pada dinding dasar wajan. Kerak timbul karena suhu wajan yang tinggi sehingga endapan bubur kedelai mengerak. Bila diaduk kerak ini akan bercampur dengan bubur kedelai sehingga menjadi kotor dan berwarna gelap (kecoklatan). Kerak tersebut menimbulkan bau tidak sedap yang akan menyebar ke seluruh bubur kedelai dan dapat mempengaruhi kualitas tahu di akhir.

Bubur kedelai yang telah dimasak kemudian disaring untuk mendapatkan sari kedelai (susu kedelai). Penyaringan yang umum dilakukan dengan meletakan bubur kedelai diatas kain belacu (mori kasar) ataupun kain sifon yang sengaja dipasang diatas bak penampung. Kemudian dilakukan pengepresan dengan memberikan papan penjepit dan diberi beban sekuat-kuatnya agar semua air yang berada pada bubur kedelai terperas semua.

Proses pengasaman atau lebih dikenal dengan penggumpalan belum menggunakan alat mesin. Penggumpalan atau pengasaman adalah proses selanjutnya setelah proses penyaringan bubur kedelai masak. Untuk menggumpalkan sari kedelai, para pengrajin menggunakan bahan asam yang dinamakan "bibit. "Bibit" adalah bahan asam sisa proses penggumpalan sehari sebelumnya. Sisa "bibit" saat penggumpalan yang tidak dapat menggumpalkan sari bubur kedelai ditampung dalam wadah ember yang selanjutnya didinginkan selama semalam untuk digunakan sebagai bahan pengasaman pada hari berikutnya.

Bubur kedelai yang telah digumpalkan selanjutnya dicetak menjadi tahu. Pengrajin tahu di Desa Adiwerna hampir semuanya menggunakan teknik cetak bungkus. Teknik cetak bungkus dilakukan dengan bantuan alat press dengan cetakan yang memiliki yang berbeda-beda sesuai dengan jenis dan ukuran tahu yang akan dibuat. Tahu yang akan dicetak sebelumnya dibungkus dengan kain belacu yang dipotong segiempat kecil-kecil. Untuk pembungkusan dan pencetakan, para pengrajin tahu memperkerjakan 2 orang dengan lama waktu pembungksan dan pencetakan adalah 30 menit untuk setiap kali masak.

Setelah proses pembungkusan dan pencetakan selanjutnya melepaskan kain belacu yang dipakai sebagai bungkus pada proses pencetakan. Untuk proses ini hanya dibutuhkan tenaga 1 orang saja. Tahu yang sudah jadi selanjutnya dapat dipasarkan. Namun sebelum dipasarkan, tahu yang sudah jadi diberi pewarna dan digarami. Untuk pemberian warna, pengrajin tahu menggunakan kunyit sebagai bahan bakunya. Ada 2 bentuk kunyit yang digunakan oleh pengrajin tahu dalam proses pewarnaan, yaitu kunyit alami (kunyit yang diparut) dan kunyit serbuk dalam kemasan. Dari hasil wawancara, kebanyakan pengrajin tahu beralih ke pengunaan kunyit serbuk kemasan sebagai bahan baku pewarna tahu. Jumlah kunyit yang dipakai adalah $1 / 4 \mathrm{~kg}$ untuk kunyit parutan (untuk 4 kali proses pewarnaan) atau $1 / 4$ ons untuk kunyit serbuk (untuk 4 kali proses pewarnaan).

Pada proses yang terdapat penyentuhan bahan baku akan menimbulkan beberapa masalah seperti adanya risiko paparan biologi dan Kimia dimana terdapat paparan zat pada bahan pembuatan tahu yang dapat menyebabkan Gangguan pada kulit maupun dalam. Masalah yang dapat timbul dapat berupa bahaya Ergonomi karena kesalahan posisi angkut wadah tahu yang 
besar sehingga dapat menyebabkan gangguan muskulo-skeletal.

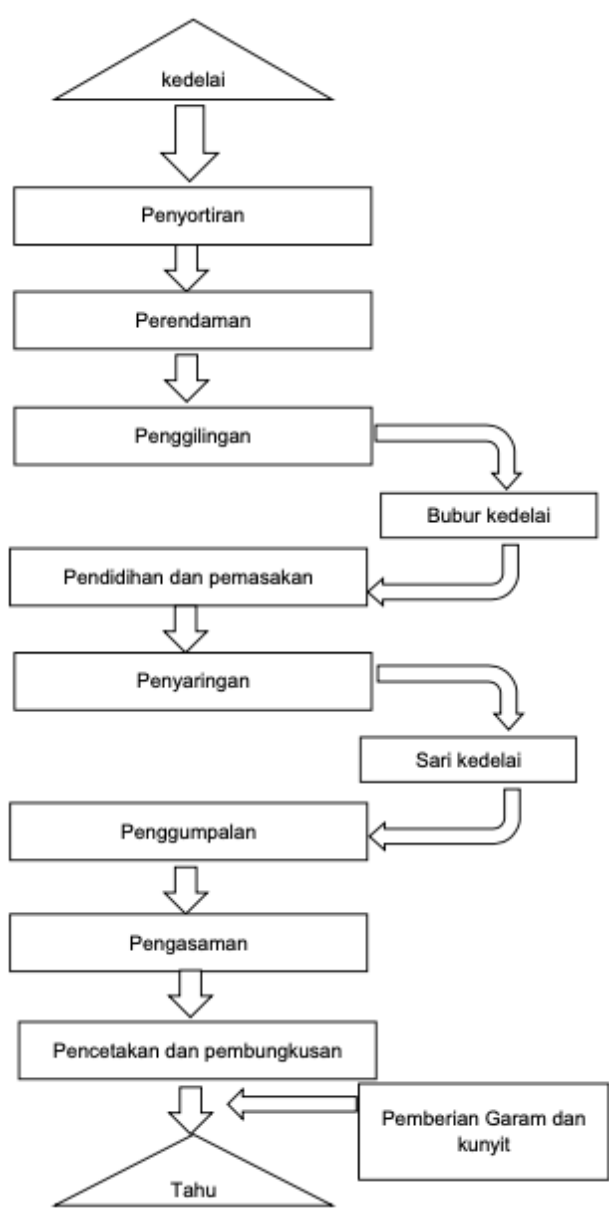

Gambar 1. Alur kerja pengolahan tahu

Penilaian bahaya di tempat kerja dinilai melalui rangakaian proses pembuatan tahu dilakukan penilaian dan didapatkan hasil sebagai berikut

Bahaya digambarkan sebagai setiap situasi, kondisi atau kejadian ekstrim (alami atau disebabkan) dengan tingkat probabilitas tertentu memiliki dan konsekuensi yang merugikan pada keselamatan atau kesehatan pekerja. Bahaya di tempat kerja merupakan setiap aktivitas yang berpotensi berdampak buruk atau negatif (mempengaruhi) kesehatan manusia, properti, atau lingkungan di tempat kerja. Bahaya tersebut dapat menyebabkan bahaya, cedera atau kematian dalam kasus yang ekstrim 9 .

Bahaya fisik adalah aktivitas yang mengancam keselamatan dan faktor lingkungan yang dapat membahayakan karyawan tanpa harus menyentuhnya, termasuk ketinggian, kebisingan, radiasi, dan tekanan. Bentuk bahaya fisik adalah yang paling umum dan terdapat di sebagian besar tempat kerja pada satu waktu atau yang lain termasuk kondisi tidak aman yang dapat menyebabkan cedera, penyakit, dan kematian ${ }^{10}$.

Bahaya biologis adalah zat organik yang menimbulkan ancaman bagi kesehatan manusia dan organisme hidup lainnya. Bahaya biologi meliputi virus, bakteri, serangga, hewan, dan lain-lain, yang dapat menimbulkan dampak buruk bagi kesehatan misalnya, jamur, darah dan cairan tubuh lainnya, tanaman berbahaya, kotoran, debu dan hama ${ }^{11}$.

Bahaya kimia adalah zat (non-biologi) yang berpotensi membahayakan kehidupan atau kesehatan. Paparan bahan kimia dapat menyebabkan efek kesehatan yang merugikan akut ataupun jangka panjang. Bahaya kimia adalah zat berbahaya yang dapat menimbulkan kerugian dan dapat mengakibatkan dampak buruk bagi kesehatan dan fisik, seperti iritasi kulit, iritasi sistem pernapasan, kebutaan, korosi dan ledakan ${ }^{12}$.

Bahaya ergonomis merupakan akibat dari faktor fisik yang dapat mengakibatkan cedera muskuloskeletal. Misalnya, pengaturan stasiun kerja yang buruk di kantor, postur tubuh yang buruk, dan penanganan manual ${ }^{13}$.

Bahaya psikososial adalah faktor dalam desain atau manajemen pekerjaan yang meningkatkan risiko stres terkait pekerjaan dan dapat menyebabkan bahaya psikologis atau fisik. Bahaya psikososial termasuk yang dapat memiliki efek buruk pada kesehatan mental atau kesejahteraan karyawan. Misalnya, pelecehan seksual, viktimisasi, stres, dan kekerasan di tempat kerja ${ }^{14}$.

Tabel di bawah ini menjelaskan elemen faktor risiko, biologi, kimia, ergonomic, dan psikologi beserta potensi bahaya.

Tabel 1. Matrik Penilaian Potensial Hazard (Hazard Rating)

\begin{tabular}{ll}
\hline \multicolumn{1}{c}{ Elemen } & \multicolumn{1}{c}{ Potensi bahaya } \\
\hline $\begin{array}{l}\text { Faktor Fisik } \\
\text { Lingkungan kerja yang } \\
\text { licin }\end{array}$ & Tergelincir/terplesset \\
Suhu lingkungan kerja & $\begin{array}{l}\text { Ketidaknyamanan, } \\
\text { yang tinggi }\end{array}$
\end{tabular}




\begin{tabular}{ll}
\hline \multicolumn{1}{c}{ Elemen } & \multicolumn{1}{c}{ Potensi bahaya } \\
\hline $\begin{array}{l}\text { Kebisingan yang } \\
\text { ditimbulkan oleh mesin } \\
\text { penggiling kedelai }\end{array}$ & Gangguan pendengaran \\
$\begin{array}{l}\text { Tangan terkena mesin } \\
\text { penggiling }\end{array}$ & Luka hingga kecacatan \\
Faktor Biologi & \\
Bakteri & Infeksi \\
Faktor Kimia & \\
$\begin{array}{l}\text { Debu sisa penggilingan } \\
\text { Faktor Ergonomi }\end{array}$ & Gangguan pernapasan \\
Posisi tubuh tidak & $\begin{array}{l}\text { Muskuloskeletal } \\
\text { disorder (Nyeri }\end{array}$ \\
rgonomis & $\begin{array}{l}\text { punggung, Low Back } \\
\text { Pain) }\end{array}$ \\
Faktor Psikologi & Kebosanan \\
\hline
\end{tabular}

Penilaian risiko dilakukan dengan berpedoman pada skala Australian Standard/New Zealand Standard for Risk Management (Standar AS/NZS) karena standar manajemen risiko ini adalah standar yang mengatur pendekatan yang sistematis untuk mengelola risiko untuk mencapai tujuan bagi suatu organisasi dan standar AS/NZS berlaku untuk semua jenis organisasi. Ada 2 parameter yang digunakan, yaitu probability dan severity ${ }^{15}$.
Tabel 2. Skala "Probabilities" pada tandar AS/NZS

\begin{tabular}{ccl}
\hline Tingkat & Deskripsi & Keterangan \\
\hline 5 & Almost & Dapat terjadi setiap \\
& certain & waktu \\
4 & Likely & Sering terjadi \\
3 & Possible & Dapat terjadi sewaktu- \\
& & waktu \\
2 & Unlikely & Jarang terjadi \\
1 & Rare & Hampir tidak pernah, \\
& & sangat jarang terjadi \\
\hline
\end{tabular}

Tabel 3. Skala "Severity" pada standar AS/NZS

\begin{tabular}{|c|c|c|}
\hline Tingkat & Deskripsi & Keterangan \\
\hline 1 & Insignificant & $\begin{array}{l}\text { Tidak terjadi cedera, } \\
\text { kerugian finansial sedikit }\end{array}$ \\
\hline 2 & Minor & $\begin{array}{l}\text { Cedera ringan, kerugian } \\
\text { finansial sedikit }\end{array}$ \\
\hline 3 & Moderate & $\begin{array}{l}\text { Cedera sedang, perlu } \\
\text { penanganan medis }\end{array}$ \\
\hline 4 & Major & $\begin{array}{l}\text { Cedera berat }>1 \text { orang, } \\
\text { kerugian besar, gangguan } \\
\text { produksi }\end{array}$ \\
\hline 5 & Catastrophic & $\begin{array}{l}\text { Fatal }>1 \text { orang, kerugian } \\
\text { sangat besar dan dampak } \\
\text { sangat luas, terhentinya } \\
\text { seluruh kegiatan }\end{array}$ \\
\hline
\end{tabular}

.Tabel 4. Hasil Observasi Bahaya dan Penilaian Risiko

\begin{tabular}{|c|c|c|c|c|c|c|c|c|}
\hline No. & $\begin{array}{l}\text { Tahapan } \\
\text { Kegiatan }\end{array}$ & $\begin{array}{c}\text { Jenis } \\
\text { bahaya }\end{array}$ & $\begin{array}{c}\text { Jenis } \\
\text { Bahaya }\end{array}$ & Dampak & Probability & Severity & $\begin{array}{c}\text { Tingkat } \\
\text { Risiko }\end{array}$ & $\begin{array}{l}\text { Pengendalian } \\
\text { risiko oleh } \\
\text { OSHA }\end{array}$ \\
\hline \multirow[t]{4}{*}{1.} & $\begin{array}{l}\text { Persiapan } \\
\text { media } \\
\text { pembuatan } \\
\text { tahu }\end{array}$ & Fisik & $\begin{array}{l}\text { Tertusuk } \\
\text { jerami }\end{array}$ & $\begin{array}{l}\text { Terkena luka } \\
\text { tusuk yang } \\
\text { dapat bersifat } \\
\text { infeksius }\end{array}$ & Sering & $\begin{array}{l}\text { Cidera } \\
\text { ringan }\end{array}$ & Medium & $\begin{array}{l}\text { Menggunakan } \\
\text { APD }\end{array}$ \\
\hline & & Fisik & $\begin{array}{l}\text { Tersiram } \\
\text { air panas }\end{array}$ & $\begin{array}{l}\text { Terkena luka } \\
\text { melepuh }\end{array}$ & Sering & $\begin{array}{l}\text { Cidera } \\
\text { ringan }\end{array}$ & Medium & $\begin{array}{l}\text { Menggunakan } \\
\text { APD }\end{array}$ \\
\hline & & Biologi & $\begin{array}{l}\text { Banyak } \\
\text { Hama } \\
\text { Tikus }\end{array}$ & $\begin{array}{l}\text { Penyakit } \\
\text { zoonosis } \\
\text { seperti } \\
\text { leptospirosis }\end{array}$ & Jarang & $\begin{array}{l}\text { Cidera } \\
\text { berat }\end{array}$ & Medium & $\begin{array}{l}\text { Menggunakan } \\
\text { APD dan } \\
\text { menangkap } \\
\text { hama }\end{array}$ \\
\hline & & Biologi & $\begin{array}{l}\text { Paparan air } \\
\text { langsung }\end{array}$ & $\begin{array}{l}\text { Terinfeksi } \\
\text { virus,bakteri , } \\
\text { dan } \\
\text { mikroorganis }\end{array}$ & Sering & $\begin{array}{l}\text { Cidera } \\
\text { ringan }\end{array}$ & Medium & $\begin{array}{l}\text { Menggunakan } \\
\text { sarung tangan } \\
\text { karet }\end{array}$ \\
\hline
\end{tabular}




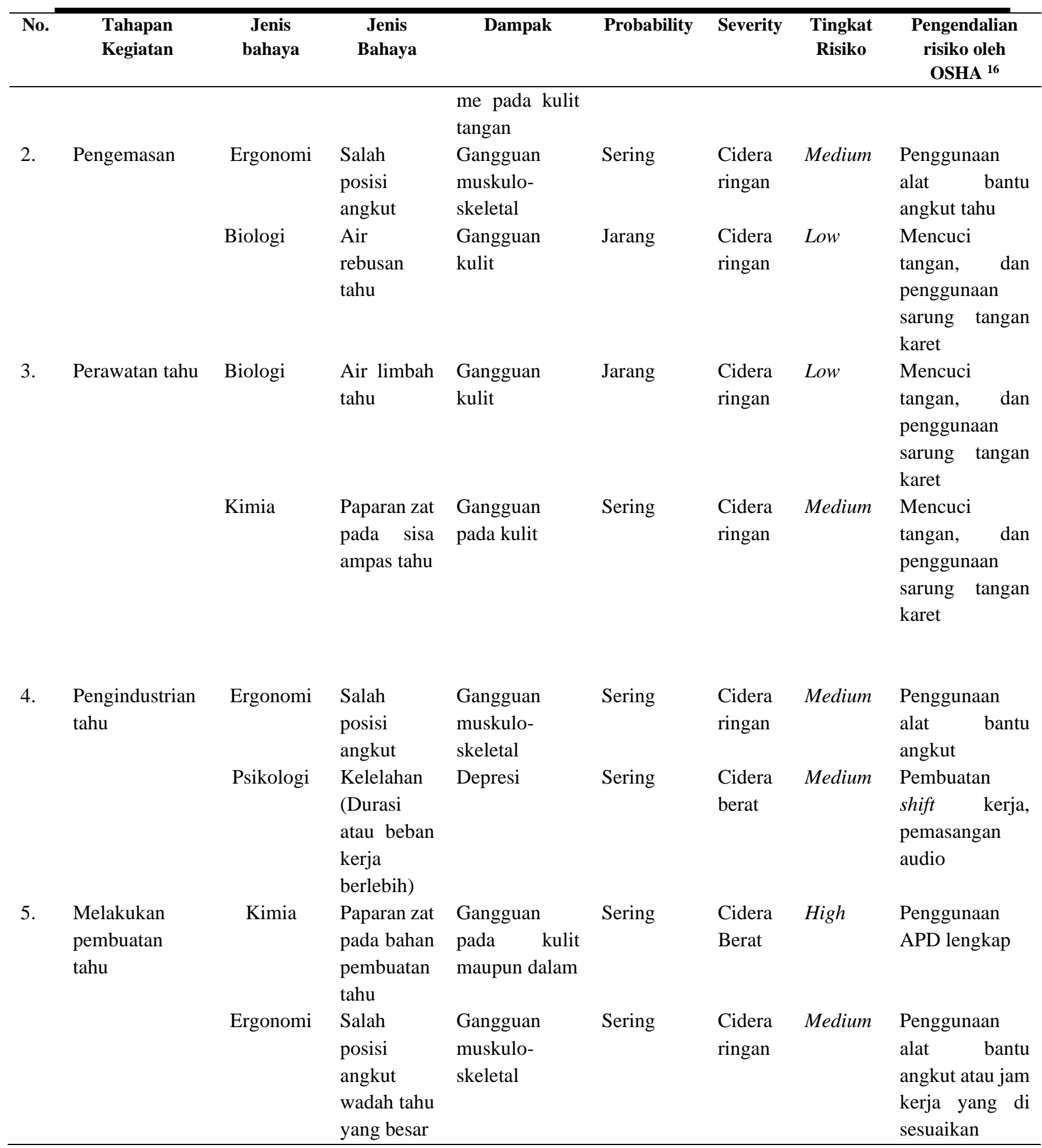

Hasil dari identifikasi bahaya potensial berguna sebagai dasar ditentukannya penilaian terhadap risiko kecelakaan kerja yang paling banyak berdampak terhadap gangguan kesehatan pekerja. Menurut survey yang telah dilakukan, proses penggilingan merupakan kegiatan yang memiliki bahaya potensial serta memiliki gangguan kesehatan yang buruk dan perlu dilakukan intervensi segera oleh pemilik usaha
Dilakukan pula analisis dan manajemen risiko dengan menggunakan pedoman tabel standar ukur probabilitas dan severity AS/NZS 4360:2004 yang merupakan standar manajemen risiko yang berasal dari Australia dan Selandia Baru (New Zealand). Setelah dilakukan analisis, didapatkan risiko dengan predikat tertinggi /High yaitu bahaya dari kebisingan ${ }^{17}$ 
Identifikasi Potensi Bahaya dan Risiko Keselamatan dan Kesehatan Kerja

Bahaya potensial yang ada pada industri ini dari segi fisik yaitu lantai yang licin dan genangan air yang dapat menjadi potensial terjadinya kecelakaan kerja berupa tergelincir hingga jatuh pada saat tidak hati-hati berjalan atau ketika tidak menggunakan alas kaki . Selain itu, pada tempat pembuatan tahu tidak digunakan sarung tangan untuk menyentuh atau pengemasan .

Bahaya potensial biologi yang mungkin terjadi pada kegiatan produksi ini adalah bakteri dan jamur yang dapat menyebabkan kontaminasi pada makanan berupa tahu yang dibuat maupun infeksi pada pekerja. Lingkungan kerja industri ini terutama pada bagian dalam ruagan pembuatan tahu dapat dikatakan kurang baik karna tidak menggunakan alat perlingdung diri . Banyaknya bakteri dan jamur mengakibatkan terjadinya timbul penyakit kulit . pada saat melakukan pekerjaan pekerja jarang menggunakan APD sehingga akan lebih berpotensi terkena bakteri, jamur, dan terinfeksi bahan - bahan yang dapat membuat timbulnya sebuah penyakit .

Bahaya potensial dari sisi ergonomi yang ada pada kegiatan produksi ini yaitu berbagai posisi tubuh saat melakukan kegiatan yang kurang ergonomis. Saat proses melakukan pencetakan tahu pekerja tidak memanfaatkan waktu untuk beristirahat sehingga pekerja harus melakukan pekerjaannya dengan waktu yang lama yang mengakibatkan terasa pegal setelah melakukan pekerjaan, dengan keadaan posisi berdiri yang cukup lama dan sedikit membungkuk.

Selain bahaya potensial fisik, kimia, biologi, dan ergonomi yang telah dijelaskan di atas, bahaya potensial yang ada pada kegiatan produksi ini adalah dari segi psikologi. Pekerja pada industri tahu ini hanya berkeja tanpa ada musik atau jarang berkomunikasi dengan pekerja lain, sehingga dimana bahaya psikologinya pekerja bisa merasakan setres dan bosan karna tidak ada kegiatan lain yang dapat dilakukan

\section{SIMPULAN DAN SARAN}

Banyak bahaya potensi kerja dapat dicegah atau diminimalkan dengan melihat aspek desain, konstruksi dan pemeliharaan. Kekurangan dalam salah satu aspek ini dapat menyebabkan pajanan yang berbahaya bagi pekerja. Berdasarkan hasil pengamatan di lapangan serta identifikasi Potensi Bahaya dan Risiko Keselamatan dan Kesehatan Kerja, ada beberapa aspek K3 yang perlu dibenahi

Komponen desain utama yang umum di banyak instalasi industri agrikultur meliputi bahan bangunan dan tata letak, penerangan, ventilasi, penyimpanan bahan berbahaya dan instalasi listrik. Aktivitas repetitif memegang sebuah beban pada pekerja terlihat saat pengadukan bahan. Hal ini akan mengakibatkan kekurangan pasukan oksigen ke otot yang akan berpengaruh pada efektivitas kerja. Sangat dianjurkan untuk istirahat setiap 15 menit selama 30 detik untuk melakukan peregangan. Pada pekerja dianjurkan memakai APD selain sepatu boots, meliputi hairnet, sarung tangan tahan panas, masker air purrifying respirator, dan apron anti bahan kimia.

Pada bagian konstruksi, lembar dan label data keselamatan bahan kimia, informasi produk tentang keselamatan dan kesehatan kerja belum disiapkan di tempat kerja. Catatan lokasi dan jenis bahan bangunan juga sebaiknya dibuat karena diperlukan bagi pekerja yang mungkin berpotensi terpapar di masa depan. Tanda potensi bahaya kerja (seperti lantai licin, suhu ruangan tinggi, dan kelembapan tinggi) sebaiknya disediakan agar baik pekerja maupun pegawai lain dapat lebih berhatihati saat memasuki kawasan kerja.

Inspeksi rutin terkait bangunan, instalasi listrik, dan alat kerja, sebaiknya dilakukan rutin. Pengetahuan terkait keselamatan kerja, kesehatan, ergonomi, serta jaminan kesehatankerja sebaiknya 
diketahui dengan baik oleh pekerja sehingga dapat meningkatkan kualitas dan kuantitas produk.

Peneliti menyarankan untuk memberikan pengetahuan tentang perlindungan dari bahan kimia paparan biologis yang berbahaya. Pastikan bahwa tenaga kerja telah dilatih tentang bahan kimia yang digunakan di ruang kerja, termasuk pertolongan pertama yang relevan, apa yang harus dilakukan jika terjadi paparan, dan mengidentifikasi karakteristik. Setelah memahami bahayanya, dapat diajari prosedur yang tepat untuk bekerja di sekitar atau bekerja dengan bahan kimia dan APD apa yang diperlukan.

Analisis bahaya menyeluruh terhadap keselamatan kerja juga harus memusatkan perhatian besar pada di mana bahaya terpeleset, tersandung, dan jatuh mungkin terjadi. Selain itu, berurusan dengan makanan sering meninggalkan zat lengket atau licin yang menggenang atau melapisi lantai. Memastikan pembersihany yang terjadwal merupakan hal yang penting untuk diberlakukan. Pekerja harus mengenakan alas kaki yang tepat yaitu dilengkapi dengan alas anti selip.

\section{UCAPAN TERIMA KASIH}

Terima kasih terhadap Fakultas Kedokteran Universitas Lampung atas dukungannya sehingga penelitian ini dapat berlansgung. Ucapan terimakasih juga ditujukan kepada House of Tofu karena telah bersedia untuk dijadikan tempat penelitian, diharapkan penelitian ini dapat bermanfaat untuk melindungi pekerja dari bahaya kerja yang dapat terjadi pada masa mendatang

\section{REFERENSI}

1. Mock CN, Nugent R, Kobusingye O, Smith KR, editors. Disease Control Priorities, Third Edition (Volume 7): Injury Prevention and Environmental Health [Internet]. The World Bank; 2017 [cited 2021 Aug 16]. Available from: http://elibrary.worldbank.org/doi/book/10.1596/ 978-1-4648-0522-6

2. Safety and health at work (Safety and health at work) [Internet]. [cited 2021 Sep 5]. Available from: https://www.ilo.org/global/topics/safetyand-health-at-work/lang--en/index.htm

3. Adei D, Braimah I, Mensah JV, Acquah Mensah A, Agyemang-Duah W. Improving upon the working environment of informal sector workers in Ghana: The role of planning. Shiri R, editor. Cogent Medicine. 2021 Jan 1;81:1911441.

4. Rangkang JR, Mautang T, Paturusi A. Hubungan Antara Pelaksanaan Program Kesehatan Keselamatan Kerja Dengan Kejadian Kecelakaan Kerja Pada PT. Cahaya Nataan Di Ratahan 2020. Physical: Jurnal Ilmu Kesehatan Olahraga. $2021 ; 2^{1}: 123-30$.

5. Hazards in the Food Processing Industry | Graphic Products [Internet]. [cited 2021 Sep 5]. Available from: https://www.graphicproducts.com/articles/hazar ds-in-the-food-processing-industry/

6. Baskaran G. Firms' approach to mitigating risks in the platinum group metals sector. Miner Econ [Internet]. 2021 Feb 8 [cited 2021 Aug 16]; Available from: http://link.springer.com/10.1007/s13563-02100249-4

7. Malik JA, Marathe S. Ecological and Health Effects of Building Materials [Internet]. Cham: Springer International Publishing AG; 2021 [cited 2021 Aug 16]. Available from: http://public.eblib.com/choice/PublicFullRecord. aspx? $\mathrm{p}=6694290$

8. Occupational Safety and Health Administration. Walking-Working Surfaces and Personal Protective Equipment (Fall Protection Systems). Final Rule. Federal register. 2016;81(223):82494-3006.

9. Sutanto SJ, Vitolo C, Di Napoli C, D'Andrea M, Van Lanen HAJ. Heatwaves, droughts, and fires: Exploring compound and cascading dry hazards at the pan-European scale. Environment International. $2020 \mathrm{Jan} ; 134: 105276$.

10. Dannoun Y, Nouban F. Occupational health hazards and risk assessments in wastewater treatment plant. IJAESA. $2021 \mathrm{Jul} 31 ; 2^{2}: 21-5$.

11. Khan AH, Aziz HA, Khan NA, Hasan MA, Ahmed S, Farooqi IH, et al. Impact, disease outbreak and the eco-hazards associated with pharmaceutical residues: a Critical review. Int J Environ Sci Technol [Internet]. 2021 Feb 10 [cited 2021 Aug 16]; Available from: 


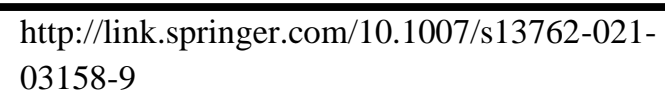

12. Saremi P. Environmental Pollution and ways to Reduce Contamination with use of Environmental Engineering Techniques in Metropolises of Developing Countries. IJEAB. 2020;53:566-81.

13. Kunda R, Frantz J, Karachi F. Prevalence and Ergonomic Risk Factors of Work-related Musculoskeletal Injuries amongst Underground Mine Workers in Zambia. Jrnl of Occup Health. 2013 May;5533:211-7.

14. Potter R, O'Keeffe V, Leka S, Webber M, Dollard M. Analytical review of the Australian policy context for work-related psychological health and psychosocial risks. Safety Science. 2019 Jan;111:37-48.

15. Dalgleish F, Cooper BJ. Risk management: developing a framework for a water authority. Management of Env Quality. 2005 Jun; $16^{3}: 235-$ 49.

16. Personal Protective Equipment - Overview | Occupational Safety and Health Administration [Internet]. [cited 2021 Sep 5]. Available from: https://www.osha.gov/personal-protectiveequipment

17. Castillo A, Bilbao A, Bilbao E. A Risk Management Method Based on the AS/NZS 4360 Standard. In IEEE; 2007. p. 64-8. 